O. Lakiza, Ph.D. tech. Sciences, Associate Professor, E-mail:0665278949ol@gmail.com

L. Rudnieva, teacher, E-mail: larisarudneva4@gmail.com

V. Vinogradova, master, E-mail:vvvnika@i.ua

\title{
OPTIMIZATION OF THE COMPOSITION AND PROPERTIES OF BAKERY PRODUCTS
}

\begin{abstract}
The article is devoted to the study of the properties of bakery products, in particular the choice of the optimal concentration of flaxseed cake in baguettes in order to ensure maximum caloric content. It is known that bakery products are necessary for a person to ensure his health and ability to work. The range of food products, in particular bakery products, is constantly growing. The analysis of the range of bakery products showed that the market is experiencing a shortage of flour products for dietary, therapeutic and prophylactic and special purposes for different groups, and their share in total production does not exceed 1-2\%. The problem of food production is becoming more complicated and exacerbated by increasing consumption, declining natural resources of food raw materials and the presence of specific anti-nutrients. The article describes the characteristics of anticancer substances in food, which belong to the groups of phytosterols and lignans.

The article presents the results of optimizing the composition and properties of wheat baguettes with the addition of linen cake, flaxseed meal. The recipe of bread with the inclusion of linen cake in the amount of 1 to 15\% was developed. The nutritional value and caloric content of bread are calculated, its characteristics are given according to the main organoleptic indicators of quality (product surface, color and thickness of the crust, as well as the condition of the crumb). The effect of the percentage of flaxseed meal on the moisture and acidity of bread samples was studied. It is established that with the increase of the content of flaxseed meal the protein content increases, the carbohydrate content decreases, the fat content and the amount of unsaturated fatty acids increase. As the content of linen cake in bread increases, the amount of unsaturated fatty acids increases and its caloric content decreases, and its nutritional value increases.

The use of flax seeds and products of their processing in the formulation of bakery and confectionery products can increase their biological value and physiological efficiency due to the content of anticancer substances, fibers, micro- and microelements, proteins and essential amino acids. Trial laboratory baking of baguettes showed that the optimal content of linen cake is $5 \%$ by weight of wheat flour, which allows you to get bread that meets the standards and does not require changes in technological parameters, which are set for the product without additives.
\end{abstract}

Key words: functional food products, bread, flax seeds, flaxseed cake (FC), flaxseed meal (FM).

\section{Introduction}

Bakery products are necessary for a person to ensure his health and efficiency. The range of food products, including bakery products, is constantly growing [1].

Human health is determined primarily by the consumption of products that are able to regulate physiological processes in the body. To this end, every year the raw material base of the baking industry expands through the use of various types of non-traditional raw materials, including products of flax seed processing, as a source of fats, proteins, dietary fiber. according to the latest data, in order to fully meet the needs of life, a person's diet should contain more than 20 thousand different food components of plant, animal and microbial origin. Functional foods are foods that are part of the normal human diet, which in addition to nutritional properties have the ability to positively affect certain body functions, so that their regular use reduces the risk of chronic diseases. Such products have a high biological value, ie have a balanced content of essential amino acids, polyunsaturated fatty acids, lipoids, polyphenolic compounds, vitamins and minerals. It is the presence of functional foods that makes it possible to ensure the normal growth and development of the human body, its health, efficiency and creative activity [2-4].
The development of modern industrial production in some way has a negative impact on the environment and, consequently, on the normal functioning of the human body. Emissions from industrial plants contain various hazardous substances with potentially carcinogenic effects, including heavy metals, radionuclides, food contaminants (dioxins, organochlorine compounds, mycotoxins), so human food must contain substances that would perform protective functions. Currently, more than 500 plant components have been identified, the ability to inhibit the development of tumor processes in the body. Characteristics of anticancer substances in food are presented in table 1 [5].

Currently, work is underway to find vegetable raw materials that can increase the nutritional value of bakery and confectionery products, improve their quality due to the additional introduction of high-protein products: cake and meal. The introduction of flax seeds and products of their processing in the recipe of bakery and confectionery products will increase their biological value and biological efficiency [6].

Today, flax seeds are used as a biologically active additive for the enrichment of bakery products, as well as raw materials for oil and such high-protein byproducts as cake and meal [7]. 
Table 1 - Characteristics of anticancer substances in food

\begin{tabular}{||l||c||c||}
\hline \hline Group of substances & $\begin{array}{c}\text { Examples of compounds or groups of } \\
\text { compounds }\end{array}$ & \multicolumn{1}{||}{ The main food sources } \\
\hline \hline Phytosterols & $\beta$-sitosterol, stigmasterol, campesterol & $\begin{array}{l}\text { All unrefined vegetable oils, soy, oats, ama- } \\
\text { ranth; vegetables fruits }\end{array}$ \\
\hline \hline Isoflavones & Ginestein, formanonetin & $\begin{array}{l}\text { Soybeans and other legumes, sunflower seeds, } \\
\text { dates, cabbage, hops }\end{array}$ \\
\hline \hline Lignans & Matairesinol, secoisolacyresinol & $\begin{array}{l}\text { Seeds of flax, sesame, pumpkin, bran, rye, } \\
\text { nuts, cherries, apples, parsley, carrots, garlic }\end{array}$ \\
\hline
\end{tabular}

Flax seeds are characterized by a sufficient content of proteins and fat, the total amount of which is 66$68 \%$ of the total mass (chemical composition is presented in Table 2).

Table 2 - Chemical composition of flax seeds, $\%$

\begin{tabular}{||l||l||}
\hline Indicators & Contents, $\%$ \\
\hline \hline Humidity & $9,26 \pm 0,08$ \\
\hline \hline Fat & $36,55 \pm 0,09$ \\
\hline \hline Protein & $30,65 \pm 0,22$ \\
\hline \hline Sugar & $4,43 \pm 0,11$ \\
\hline \hline Hemicellulose & $7,80 \pm 0,15$ \\
\hline \hline Cellulose & $13,30 \pm 0,22$ \\
\hline \hline Ash & $4,18 \pm 0,32$ \\
\hline \hline
\end{tabular}

It is known that flaxseed oil is a source of polyunsaturated essential fatty acids (PNFA) - 65-90\%, of which $55-70 \%$ is linolenic acid, which belongs to the family $\omega-3$, and 10-20\% - linoleic acid, $\omega-6$. The fatty acid composition of linseed oil is shown in table 3 [8].

Table 3 - Fatty acid composition of linseed oil

\begin{tabular}{||l||l||}
\hline Fatty acids & Contents, \% \\
\hline \hline Palmitic & 5,0 \\
\hline \hline Stearic & 3,0 \\
\hline \hline Arachidic & 0,7 \\
\hline \hline Пальметолеїнова & 0,3 \\
\hline \hline Оleic & 16,0 \\
\hline \hline Linoleic & 15,0 \\
\hline \hline Ліноленова & 60,0 \\
\hline
\end{tabular}

Flax seeds contain the following biologically and physiologically active substances: polyunsaturated fatty acids of the $\omega-3$ family, soluble dietary fiber in the form of mucus and lignans that have a phytoestrogenic effect. The protein content in flax seeds is in the range of
$20-30 \%$, and in the proteins themselves a small amount of lysine, but they have a high coefficient of digestibility $(89.6 \%)$ and biological value $(77.4 \%)$. In addition, flaxseed proteins are rich in sulfur-containing amino acids cysteine and methionine, which have antioxidant and geroprotective properties [9].

Flax seeds contain lignans - most of them are contained in the shell of flax seeds $(800 \mu \mathrm{g} / \mathrm{g})$. Lignans differ in many functional properties, such as: antiviral, antibacterial, antifungal, antioxidant (more powerful than vitamin E), phytoestrogenic and oncoprotective. The human intestinal microflora converts plant lignans into two substances - enterolactone and enterodiol, which are means of protection against cancer [5].

Flaxseed protein has the full composition of essential amino acids for the human body, because flaxseed, which is eaten, does not require pre-heat treatment, which leads to changes in the protein molecule. In this regard, it retains its biological activity and is a valuable raw material for protein products [10].

According to the data presented in the article [11], the protein fractions of flax seeds contain a complete set of amino acids, which confirms their high biological value: arginine, leucine, valine, phenylalanine and threonine.

Due to the valuable chemical composition of flax, in the last decade in the developed world there is an active consumption. In the food industry for the manufacture of various food products use whole and crushed flax seeds, flaxseed flour, linseed oil and secondary products of its processing - cake and meal [12].

\section{The experimental part}

Trial laboratory baking of baguettes with replacement of wheat flour with flaxseed cake (FC) was carried out under the same conditions and analyzed in quantities of $1 ; 2 ; 3 ; 4 ; 5 ; 10$ and $15 \%$ (Table 5) obtained samples of bread.

Table 5 - Recipe for bread samples

\begin{tabular}{||l||l||l||l||l||l||l||l||l||l||}
\hline \hline Ingredient & $\mathrm{CI}$ & Control & $1 \% \mathrm{FC}$ & $2 \% \mathrm{FC}$ & $3 \% \mathrm{FC}$ & $4 \% \mathrm{FC}$ & $5 \% \mathrm{FC}$ & $10 \% \mathrm{FC}$ & $15 \% \mathrm{FC}$ \\
\hline \hline Flour & $\mathrm{kg}$ & 0,350 & 0,3465 & 0,343 & 0,3395 & 0,336 & 0,333 & 0,315 & 0,298 \\
\hline \hline $\begin{array}{l}\text { Flaxseed cake } \\
(\mathrm{LC})\end{array}$ & $\mathrm{kg}$ & - & 0,0035 & 0,007 & 0,0105 & 0,014 & 0,017 & 0,035 & 0,052 \\
\hline \hline Salt & $\mathrm{kg}$ & 0,007 & 0,007 & 0,007 & 0,007 & 0,007 & 0,007 & 0,007 & 0,007 \\
\hline \hline Yeast & $\mathrm{kg}$ & 0,007 & 0,007 & 0,007 & 0,007 & 0,007 & 0,007 & 0,007 & 0,007 \\
\hline \hline Sugar & $\mathrm{kg}$ & 0,004 & 0,004 & 0,004 & 0,004 & 0,004 & 0,004 & 0,004 & 0,004 \\
\hline \hline Oil & $\mathrm{kg}$ & 0,004 & 0,004 & 0,004 & 0,004 & 0,004 & 0,004 & 0,004 & 0,004 \\
\hline \hline Water $\left(10-12^{\circ} \mathrm{C}\right)$ & $\mathrm{kg}$ & 0,193 & 0,193 & 0,193 & 0,193 & 0,193 & 0,193 & 0,193 & 0,193 \\
\hline
\end{tabular}


Table 6 - Estimated nutritional value of bread samples

\begin{tabular}{|c|c|c|c|c|c|c|c|c|}
\hline Sample & Control & 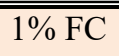 & $2 \% \mathrm{FC}$ & $3 \% \mathrm{FC}$ & $4 \% \mathrm{FC}$ & 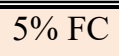 & $10 \% \mathrm{FC}$ & $15 \% \mathrm{FC}$ \\
\hline Proteins & $\overline{77,01}$ & 7,08 & $7 \overline{7,14}$ & $7 \overline{7,18}$ & $7,7,16$ & $7,7,11$ & 7,52 & $7,7,81$ \\
\hline Fat & 1,52 & 1,58 & $1,1,63$ & $\bar{~} 1,67$ & $1,1,70$ & $1,1,72$ & $1,1,98$ & 2,21 \\
\hline Carbohydrates & 47,36 & 46,80 & 46,15 & 45,34 & 44,22 & 43,12 & 40,80 & 38,23 \\
\hline
\end{tabular}

Table 7 - Caloric content of bread samples

\begin{tabular}{|l||l||l||l||l||l||l||l||l||}
\hline \hline Sample & Control & $1 \% \mathrm{FC}$ & $2 \% \mathrm{FC}$ & $3 \% \mathrm{FC}$ & $4 \% \mathrm{FC}$ & $5 \% \mathrm{FC}$ & $10 \% \mathrm{FC}$ & $15 \% \mathrm{FC}$ \\
\hline \hline Caloric content, kcal/100 g & 231 & 230 & 228 & 225 & 221 & 216 & 211 & 204 \\
\hline
\end{tabular}

Table 8 - Characteristics of bread samples

\begin{tabular}{|c|c|c|c|c|}
\hline Indicator & Control & $1-5 \% \mathrm{FC}$ & $10 \% \mathrm{FC}$ & $15 \% \mathrm{FC}$ \\
\hline $\begin{array}{l}\text { Mass of bread, } \\
\mathrm{g}\end{array}$ & 527 & $529,532,537,546,556$ & 562 & 574 \\
\hline Form & \multicolumn{3}{|c|}{ Correct, symmetrical, has a convex upper crust without lateral inflows } & $\begin{array}{l}\text { Not symmetrical, has a } \\
\text { convex upper crust } \\
\text { without lateral inflows }\end{array}$ \\
\hline $\begin{array}{l}\text { The surface of } \\
\text { the product }\end{array}$ & $\begin{array}{l}\text { - Smooth, slightly } \\
\text { shiny; } \\
\text { - without cracks and } \\
\text { tears; } \\
\text { - not contaminated }\end{array}$ & $\begin{array}{l}\text { - Almost smooth, slight- } \\
\text { ly shiny; } \\
\text { - with a crack along the } \\
\text { upper face, but without } \\
\text { gaps; } \\
\text { - not contaminated }\end{array}$ & $\begin{array}{l}\text { - Almost smooth, } \\
\text { slightly shiny; } \\
\text { - without cracks and } \\
\text { tears; } \\
\text { - not contaminated }\end{array}$ & $\begin{array}{l}\text { - Almost smooth, } \\
\text { slightly shiny; } \\
\text { - with cracks and hol- } \\
\text { lows; } \\
\text { - not contaminated }\end{array}$ \\
\hline Crust color & $\begin{array}{l}\text { - uniform, not pale, } \\
\text { not burnt; } \\
\text { - yellow }\end{array}$ & $\begin{array}{l}\text { - not uniform (with pro- } \\
\text { nounced spots - inclu- } \\
\text { sion of FC), not pale, } \\
\text { not burnt; } \\
\text { - light brown }\end{array}$ & $\begin{array}{l}\text { - not uniform(with } \\
\text { pronounced spots - } \\
\text { inclusion of FC), not } \\
\text { pale, not burnt; } \\
\text { - light brown, but } \\
\text { darker, than previous }\end{array}$ & $\begin{array}{l}\text { - not uniform(with } \\
\text { pronounced spots - } \\
\text { inclusion of FC), not } \\
\text { pale, not burnt; } \\
\text { - dark brown }\end{array}$ \\
\hline $\begin{array}{l}\text { Crust } \\
\text { thickness, mm }\end{array}$ & $1,5-2$ & $1,5-2$ & $1-1,5$ & $1-1,5$ \\
\hline \multirow[t]{4}{*}{$\begin{array}{l}\text { Crumb } \\
\text { condition }\end{array}$} & \multicolumn{4}{|c|}{$\begin{array}{l}\text { Almost uniform, small, thin-walled porosity with small cavities. The size of the pores decreases } \\
\text { slightly with increasing of FC content. No signs of hardening, no outside inclusions in the form of } \\
\text { lumps. }\end{array}$} \\
\hline & Color-white. & Color - grey. & Color-dark. & Color - dark. \\
\hline & \multicolumn{4}{|c|}{ Well baked, not sticky or moist. } \\
\hline & Soft, elastic & Soft, elasticity -medium & $\begin{array}{l}\text { Not very soft, elastici- } \\
\text { ty - medium }\end{array}$ & $\begin{array}{l}\text { Not very soft, elastici- } \\
\text { ty - medium }\end{array}$ \\
\hline Taste & normal & normal & & \\
\hline Smell & \multicolumn{4}{|c|}{ Corresponds to the product, no foreign odors } \\
\hline
\end{tabular}

Table 6 shows the estimated nutritional value of bread samples, provided that the nutritional value of the components per $100 \mathrm{~g}$ is as follows: wheat flour $\mathrm{h} / \mathrm{g}$ proteins 10.3 , fats $1.1 \mathrm{~g}$, carbohydrates 70.0 ; LV - proteins $25.5 \mathrm{~g}$, fats $10.0 \mathrm{~g}$, carbohydrates 12,0 ; salt and water - proteins $0 \mathrm{~g}$, fats $0 \mathrm{~g}$, carbohydrates $0 \mathrm{~g}$; yeast proteins $12.7 \mathrm{~g}$, fats $2.7 \mathrm{~g}$, carbohydrates $8.5 \mathrm{~g}$; sugar - 0 $\mathrm{g}$ of proteins, $0 \mathrm{~g}$ of fats, $99.9 \mathrm{~g}$ of carbohydrates; oil proteins $0 \mathrm{~g}$, fats $99.9 \mathrm{~g}$, carbohydrates $0 \mathrm{~g}$.

As the FC content increases, the protein content increases, the carbohydrate content decreases, the fat content and the amount of unsaturated fatty acids increase. This changes the ratio of various carbohydrates and fatty acids in fats, amino acids in proteins. With increasing FC content, the amount of unsaturated fatty acids increases.
Table 7 shows the caloric content of bread samples containing FC.

The introduction of FC reduces the caloric content of the finished product and improves its nutritional value due to unsaturated fatty acids, fiber, vitamins and minerals contained in the cake.

Table 8 shows the characteristics of bread samples.

According to GOST 27842-88 all samples almost correspond to norms. There should have been no cracks [13].

Table 9 shows the results of determining the moisture content of bread samples. The results show Figure 1 that the moisture content of bread increases slightly with increasing FC content, which is due to the high water holding capacity of flax cake. 
Table 9 - The results of determining the moisture content of bread samples

\begin{tabular}{|c|c|c|c|c|c|c|c|c|}
\hline ample & Control & $1 \% \mathrm{FC}$ & $2 \%$ FC & $3 \% \mathrm{FC}$ & 4\% FC & 5\% FC & $10 \% \mathrm{FC}$ & $15 \% \mathrm{FC}$ \\
\hline Fumidity & $\begin{array}{l}42,49 \\
\end{array}$ & 42,51 & $\bar{~} \overline{42,74}$ & 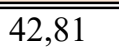 & 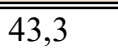 & 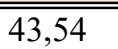 & 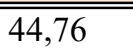 & "44,76 \\
\hline
\end{tabular}

Table 10 - The results of determining the acidity of bread

\begin{tabular}{|c|c|c|c|c|c|c|c|c|}
\hline San & \begin{tabular}{|l|} 
Control \\
\end{tabular} & $1 \% \mathrm{FC}$ & $2 \% \mathrm{FC}$ & $3 \% \mathrm{FC}$ & $4 \% \mathrm{FC}$ & $5 \% \mathrm{FC}$ & $10 \% \mathrm{FC}$ & $15 \% \mathrm{FC}$ \\
\hline Sourpuss, \% & 0,84 & 0,95 & 0,95 & 0,95 & 1,05 & 1,16 & 1,16 & 1,27 \\
\hline
\end{tabular}

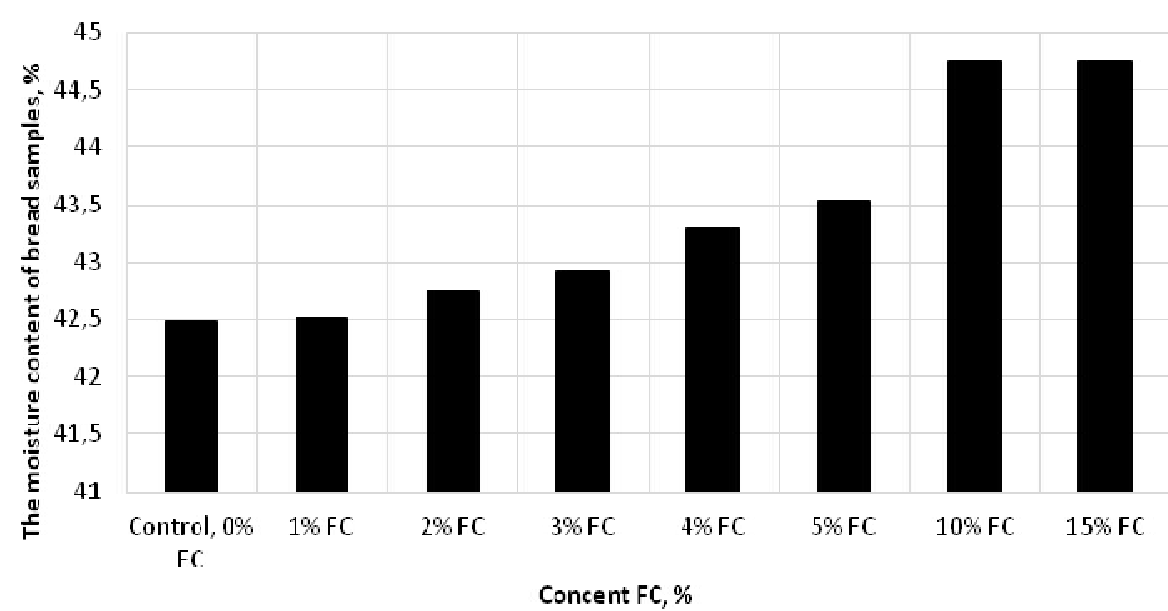

Fig. 1. Dependence of bread moisture on the content of flax cake

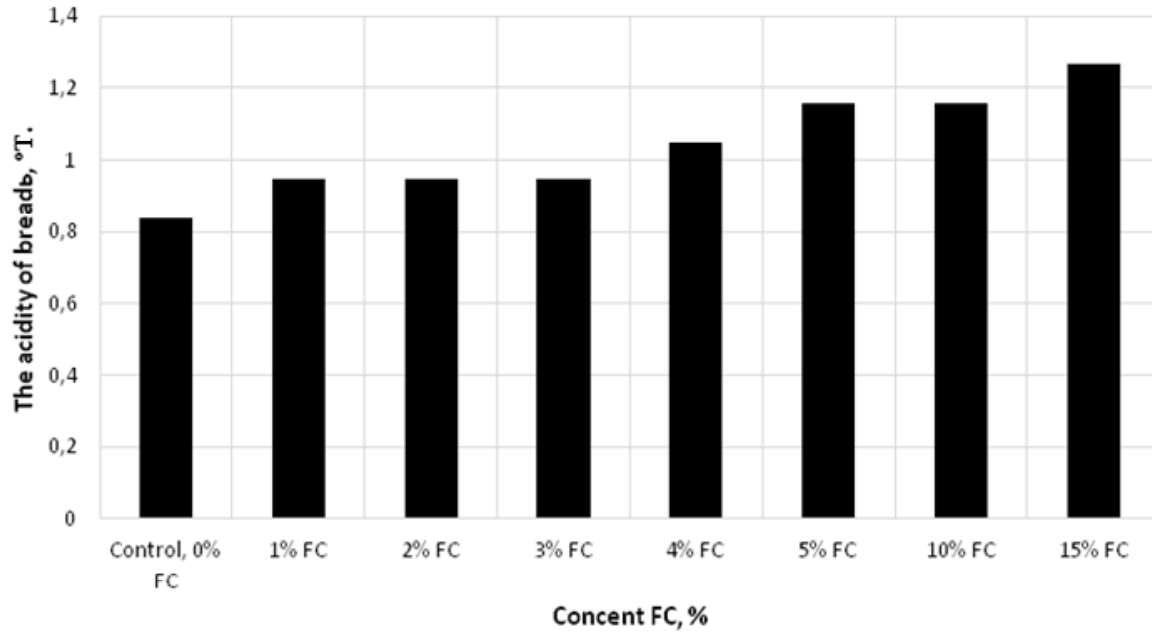

Fig. 2. Dependence of bread acidity on the content of flax cake

According to GOST 27842-88, the moisture content of wheat bread (from high-grade flour) should not exceed $44 \%$ [13]. Samples for the introduction of FC up to $5 \%$ inclusive meet the norm, and with the subsequent introduction of the FC humidity is slightly above normal.

The acidity of bread samples was also determined, the results of the study are shown in table 10 in figure 2.

Total acidity is characterized by the total content of acids and acid-reactive substances. The acidity of bread is due to the presence in it mainly of lactic and acetic acids, which are formed during the fermentation of the dough [14]. According to the results of determining

iological efficiency. body. without additives. the acidity, we can conclude that the introduction of FC has almost no effect on the acidity of bread. All samples meet the acidity standards in accordance with GOST 27842-88 (acidity for wheat bread should not exceed 3 degrees [13]).

According to the obtained characteristics of the experimental samples of bread, the optimal content of FC is $5 \%$ by weight of flour in the recipe. Studies have shown that the addition of FC in the optimal concentration reduces the caloric content of bread and improves its nutritional value due to unsaturated fatty acids, fiber, vitamins and minerals contained in flaxseed meal.

\section{Conclusions}

Bakery products are necessary for a person to ensure his health and efficiency. The range of food products, including bakery products, is constantly growing. To address this need, flax seeds and products of their processing are introduced into the recipe of bakery and confectionery products, which will increase their biological value and phys-

Flax seeds contain anticancer substances, fibers, micro- and microelements, proteins that are necessary for the functioning of the body, as well as essential amino acids that affect the assimilation of the product by the

According to the results of the experiment, it can be argued that the introduction of FC in quantities not exceeding $5 \%$ by weight of wheat flour produces bread that meets the standards and does not require changes in technological parameters set for the product

\section{REFERENCES}

1. Ivanov S.V. Pokrashhennya vitaminnogo ta mineralnogo skladu khlibobulochnikh virobiv za rakhunok vikoristannya netradiczijnoyi sirovini [Tekst] / S.V. Ivanov, N.P. Shapovalova, O.Yu. Demidko // Mizhnarodna naukovo-tekhnichna konferencziya «Yakist i bezpeka kharchovikh produktiv»: 36. tez / Nacz. univ-t kharch. tekhnologij. - Kiyiv: NUKhT. - 189 $s$. 
2. Lakiza, O. V. Osoblivosti suchasnogo virobnicztva khlibobulochnikh virobiv z dodavannyam produktiv pererobki zerna kukurudzi [Tekst] / O. V. Lakiza, L. V. Sidorchuk // Khranenie i pererabotka zerna. - Dnipropetrovsk, 2016. - \# 12. - S. 52-55.

3. Lakiza O.V. Zastosuvannya funkczionalnikh produktiv u khlibopekarskomu ta konditerskomu virobnicztvakh [Tekst] / Lakiza O.V., Ishhenko K.Yu., Naumenko O.P., Troyekurova V.O. // Khranenie i pererabotka zerna - 2018. - \# 5-6. - S. 4042.

4. Izhevska, O.P. Vpliv shrotu nasinnya lonu na tekhnologichnij proczes ta yakist khliba / O.P. Izhevska // Tekhnologichni aspekti pidvishhennya konkurentospromozhnosti khliba i khlibobulochnikh virobiv [Tekst]: Mizhnarodna naukovopraktichna konferencziya, 13 veresnya 2016 r.: tezi dopovidej. — K.: NUKhT, 2016. - S. 40-41.

5. Ivashkiv L.Ya. Novi klasi ingrediyentiv produktiv kharchuvannya ta yikhni funkczionalni vlastivosti [Tekst] / Ivashkiv L.Ya. // Problemi kharchuvannya. - 2010.-\#3-4. - S. 61-65.

6. Tarajmovich I.V. Mozhlivosti rozshirennya asortimentu produktiv kharchuvannya za rakhunok misczevoyi olijnoyi sirovini [Tekst] / Tarajmovich I.V // Suchasni tekhnologiyi mashinobuduvannya ta transporti - 2015 - 167-171 s

7. Krayevska S.P. Oczinyuvannya yakosti bilka nasinnya lonu metodom DIAAS / S.P. Krayevska,. Steczenko, G.M. Bandurenko, // Zernovi produkti i kombikormi-2018. - \#18. - S. 10-15.

8. Koval O.A. Nasinnya lonu - najbagatshe dzherelo biologichno aktivnikh rechovin/ Koval O.A., Skripka Ya.I // Young Scientist-2017. - \#11 (51). - S. 35-37.

9. Gumenyuk O.L.. Rozroblennya reczepturi khliba z vikoristannyam llyanogo shrotu / O.L. Gumenyuk, M.P. Ksenyuk, I.M. Zhurok, M.V. Drozhinska // Visnik Chernigivskogo derzhavnogo tekhnologichnogo universitetU - 2015 - 184-190 s.

10. Klevczov K.M. Tekhnologiya oderzhannya biologichno aktivnikh dobavok z nasinnya lonu ta konopel / K.M. Klevczov // Vestnik KhNTU - 2015. - \#4(55). - S. 188-123.

11. Lakiza, O. V. Efektivnist zastosuvannya visokobilkovikh funkczionalnikh produktiv u virobnicztvi bulochok / O.V. Lakiza, K.P. Maslikova, M.V. Ishhenko // Zernovi produkti i kombikormi. - 2018-26-29 s.

12. Bondarenko Yu.V. Vikoristannya urbechu z nasinnya lonu u virobnicztvi pshenichnogo khliba / Yu.V. Bondarenko, V.I. Drobot, O.A. Bilik, Ya.I. Bilas // Kharchovi tekhnologiyi - 2017-228-236 s.

13. GOST 27842-88. Khleb iz pshenichnoj muki. Tekhnicheskie usloviya. - Moskva: Izd-vo standartov. -9 s.

14. Metody issledovaniya kachestva khlebobulochnykh izdelij: uchebno-metodicheskoe posobie dlya vuzov [Tekst] / S.Ya. Koryachkina, N.A. Berezina, E.V. Khmeleva. - Orel: OrelGTU, 2010. - 166 s.

\section{УДК 664.661:664.696,3:005.336.1}

О.В. Лакіза, канд. техн. наук, доцент, E-mail: 0665278949ol@gmail.com Л.Л. Руднєва, викладач, E-mail: larisarudneva4@gmail.com В.В. Виноградова, магістр, E-mail: vvvnika@i.ua Український державний хіміко-технологічній університет, м. Дніпро, Украӥна

\section{ОПТИМІЗАЦІЯ СКЛАДУ І ВЛАСТИВОСТЕЙ ХЛІБОБУЛОЧНИХ ВИРОБІВ}

\section{Анотація}

Стаття присвячена вивченню властивостей хлібобулочних виробів, зокрема вибору оптимальної концентрації лляного жмиха в багетах з метою забезпечення максимальної калорійності. Відомо, щзо хлібобулочні вироби необхідні людині для забезпечення ї̈ здоров'я та прачездатності. Асортимент харчових продуктів, зокрема хлібобулочних виробів, постійно зростає. Проведений аналіз асортименту хлібобулочних виробів показав, щзо на ринку відчувається певний дефіцит борошняних виробів дієтичного, лікувально-профілактичного та спечіального призначення для різних груп населення, і їхня частка в загальному обсязі виробництва не перевищує 1-2 \%. Проблема виробництва харчових продуктів дедалі ускладняється $і$ загострюється через зростання споживання, зменшення природних ресурсів харчової сировини та присутністю специфічних антипоживних речовин. В статті наведена характеристика антиканцерогенних речовин у продуктах харчування, які відносяться до груп фітостеринів і лігнанів.

В статті представлено результати оптимізації складу і властивостей пшеничних багетів з додаванням лляної макухи. Розроблена рецептура хлібу з включенням лляної макухи у кількості від 1 до $15 \%$. Розраховані харчова иінність та калорійність хліба, надана його характеристика за основними органолептичними показниками якості (поверхня виробу, колір і товщчна скоринки, а також стан м'якушки). Досліджено вплив відсотку введення лляної макухи на вологість і кислотність зразків хлібу. Встановлено, щзо зі збільшенням вмісту лляної макухи збільшується вміст білку, зменшується вміст вуглеводів, збільшується вміст жирів та кількість ненасичених жирних кислот. Зі збільшенням вмісту лляної макухи в хлібі збільшується кількість ненасичених жирних кислот та зменшується його калорійність, підвищується харчова иінність.

Використання насіння льону і продуктів їх переробки в рецептурі хлібобулочних $і$ кондитерських виробів дозволяє підвищити їх біологічну цінність і фізіологічну ефективність за рахунок вмісту антиканцерогенних речовин, волокон, мікро- і мікроелементів, білків та незамінних амінокислот. Пробна лабораторна випічка багетів показала, щуо оптимальний вміст лляної макухи складає 5 \% від маси пшеничного борощна, що дозволяє отримати хліб, який відповідає нормам і не потребує змін технологічних параметрів, які встановлено для виробу без внесення добавки.

Ключові слова: функиіональні харчові продукти, хліб, насіння льону, льняна макуха. 


\section{ЛIТЕРАТУРА}

1. Іванов С.В. Покращення вітамінного та мінерального складу хлібобулочних виробів за рахунок використання нетрадииійної сировини [Текст] / С.В. Іванов, Н.П. Шаповалова, О.Ю. Демидко // Міжнародна науково-технічна конференція «Якість і безпека харчових продуктів»: 36. тез / Нац. унів-т харч. технологій. - Київ: НУХТ. - 189 с.

2. Лакіза, О. В. Особливості сучасного виробництва хлібобулочних виробів з додаванням продуктів переробки зерна кукурудзи [Текст] / О. В. Лакіза, Л. В. Сидорчук // Хранение и переработка зерна.Дніпропетровськ, 2016. - № 12. - С. 52-55.

3. Лакіза О.В. Застосування функиіональних продуктів у хлібопекарському та кондитерському виробництвах [Текст] / Лакіза О.В., Іщенко К.Ю., Науменко О.П., Троєкурова В.О. // Хранение и переработка зерна - 2018. - № 5-6. - C. 40-42.

4. Іжевська, О.П. Вплив шроту насіння льону на технологічний процес та якість хліба / О.П. Іжевська // Технологічні аспекти підвищення конкурентноспроможності хліба і хлібобулочних виробів[Текст]: Міжнародна науковопрактична конферениія, 13 вересня 2016 р.: тези доповідей. - К.: НУХТ, 2016. C. 40-41.

5. Івашків Л.Я. Нові класи інгредієнтів продуктів харчування та їхні функціональні властивості [Текст] / Івашків Л.Я. // Проблеми харчування. - 2010.-№3-4. - С. 61-65.

6. Тараймович І.В. Можливості розширення асортименту продуктів харчування за рахунок місиевої олійної сировини [Текст] / Тараймович I.B // Сучасні технологї машинобудування та транспорті $2015-167-171 c$

7. Краєвська С.П. Оцінювання якості білка насіння льону методом DIAAS / С.П. Краєвська, Стеценко, Г.М. // Зернові продукти і комбікорми - 2018. - №18. - С 10-15.

8. Коваль О.А. Насіння льону - найбагатше джерело біологічно активних речовин / Коваль О.А., Скрипка Я.I //Young Scientist - 2017. - № 11 (51). - C. 35-37.

9. Гуменюк О.Л. Розроблення рецептури хліба з використанням лляного шроту / О.Л. Гуменюк, М.П. Ксенюк, І.М. Журок, М.В. Дорожинська // Вісник чернігівського державного технологічного університетУ $-2015-184-190 c$

10. Клевиов К.М. Технологія одержання біологічно активних добавок з насіння льону та конопель / К.М. Клевиов // Вестник ХНТУ - 2015. - № 4(55). - С. 188-123.

11. Лакіза, О. В. Ефективність застосування високобілкових функціональних продуктів у виробниитвві булочок/ О.В. Лакіза, К.П. Маслікова, М.В. Іщенко // Зернові продукти і комбікорми. - 2018 - 26-29 с.

12. Бондаренко Ю.В. Використання урбечу з насіння льону у виробниитві пшеничного хліба / Ю.В. Бондаренко, В.І. Дробот, О.А. Білик, Я.І. Білас // Харчові технології- 2017 - 228-236 с.

13. ГОСТ 27842-88. Хлеб из пшеничной муки. Технические условия. - Москва: Изд-во стандартов. - 9 с.

14. Методы исследования качества хлебобулочных изделий: учебно-методическое пособие для вузов [Текст] / С.Я. Корячкина, Н.А. Березина, Е.В. Хмелева. - Орел: ОрелГТУ, 2010. - 166 с.

Received 14.07.2020

Reviewed 03.08.2020
Revised 20.08.2020 Approved 28.08.2020

Cite as Vancouver Citation Style

Lakiza O., Rudnieva L., Vinogradova V. Optimization of the composition and properties of bakery products. Grain Products and Mixed Fodder's, 2020; 20 (3, 79): 28-33. DOI https://doi.org/

Cite as State Standard of Ukraine 8302:2015

Optimization of the composition and properties of bakery products / Lakiza O. et al. // Grain Products and Mixed Fodder's. 2020. Vol. 20, Issue 3 (79). P. 28-33. DOI https://doi.org/

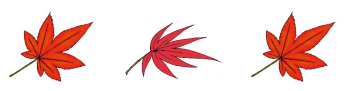

